\title{
Formação Profissional: a interface das práticas de saúde com as Ciências Sociais e Humanas
}

A formação em saúde passou ao longo dos anos por reestruturações que contribuíram para uma análise crítica da produção de conhecimento voltado para o modelo flexneriano. Buscou-se ampliar a visão curativa e individual para que as ações propostas pudessem se tornar eficazes nas realidades locais. Desta forma evidencia-se que a formação do profissional que atuará na saúde tenha interface com as ciências sociais e humanas, na busca de responder às necessidades das populações, organizações e serviços, compreendendo desta forma a produção da saúde como um direito social.

No entanto, ao analisar a relação entre o conhecimento e a prática, verifica-se que o senso comum contemporâneo acaba reduzindo essa relação à dimensão tecnológica, que é predominante no discurso da sociedade moderna, na qual, se acredita que o trabalho e as práticas humanas seriam regulados pelo saber previamente acumulado. É imprescindível destacar que as ações de saúde necessitam retirar o foco da doença e voltar-se para o seu objeto de trabalho, ou seja, o homem e suas relações humanas. Mas, esta mudança de paradigma é permeada de complexidade, pois exige do profissional, atitude reflexiva e criativa para lidar com as construções sociais de cada época e de cada sujeito e não meramente resumir suas ações a aplicação automática de condutas pré-estabelecidas.

As formações devem articular elementos afetivos, mentais e sociais que possam oferecer subsídios para intervir na realidade material, social e ideativa. Desta forma é necessário que os setores da educação e da saúde possam estabelecer uma rede de comunicação que possibilite a construção de uma proposta pedagógica que conjugue os conhecimentos produzidos e acumulados por todas as áreas. É preciso, portanto, construir um processo educacional que articule a formação profissional com as necessidades e as demandas da sociedade, na perspectiva de possibilitar ao indivíduo o exercício eficiente de seu trabalho, a responsabilização com o outro e uma postura crítica capaz de enfrentar barreiras socialmente impostas, além de sua efetiva autorealização.

Grandes desafios emergem cotidianamente no processo educacional exigindo a integração entre pensar e fazer, a fim de desenvolver habilidades comunicativas, sociais e comportamentais que sustentem as ações de cada profissional possibilitando a construção de uma identidade social e plena de cidadania. Nessa ótica, o conceito de educação deve ser entendido como um compromisso com os ideais da sociedade.

As Ciências Sociais e Humanas podem contribuir com a reflexão constante sobre os meios e os modos como a formação profissional vem ocorrendo, além da necessidade de que os conteúdos curriculares possam sofrer influências de diversas áreas do conhecimento. Acresce-se a isto, a importância do uso de metodologias de ensino que permitam ao aluno apreender tanto os procedimentos técnicos indispensáveis ao exercício profissional como, também, desenvolver hábitos, atitudes e valores éticos comprometidos com o entendimento do contexto social, priorizando o homem e suas ações no mundo, consolidando assim, uma nova tecnologia para acolher as necessidades de saúde.

A todos um Feliz ano novo e Boa Leitura!

Profa. Dra. Grasielle Silveira Tavares Paulin Lider do NEPHEL, pesquisadora do CIFACS e Membro do Conselho Diretor da REFACS/UFTM 